\title{
Prevalence and Demographic Characteristics of Prostate Cancer Patients in Colombia: data from the National Health Registry from 2015 to 2019
}

\section{Prevalencia y características demográficas de pacientes con cáncer de próstata en Colombia: datos del Registro de Salud Nacional de 2015 a 2019}

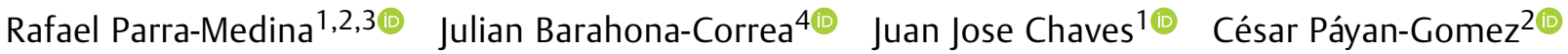 \\ Sandra Ramirez-Clavijo ${ }^{20}$ Daniel G. Fenández-Ávila ${ }^{4,5,6(0)}$ Diego Rosselli6(0) \\ ${ }^{1}$ Department of Pathology, Instituto de Investigación, Fundación \\ Universitaria de Ciencias de la Salud, Bogotá, Colombia \\ 2 Departamento de Biología, Facultad de Ciencias Naturales y \\ Matemáticas, Universidad del Rosario, Bogotá, Colombia \\ ${ }^{3}$ Department of Pathology, Instituto Nacional de Cancerología, \\ Bogotá, Colombia \\ ${ }^{4}$ Department of Internal Medicine, Pontificia Universidad Javeriana, \\ Bogotá, Colombia \\ Address for correspondence Rafael Parra-Medina, MD, PhD, \\ Departamento de Patología, Instituto de Investigación, Fundación \\ Universitaria de Ciencias de la Salud, Carrera 19, 8A-32, Bogotá, \\ Colombia (e-mail: Rafa.parram@gmail.com). \\ ${ }^{5}$ Department of Rheumatology, Department of Internal Medicine, \\ Hospital Universitario San Ignacio, Bogotá, Colombia \\ ${ }^{6}$ Department of Clinical Epidemiology and Biostatistics, Facultad de \\ Medicina, Pontificia Universidad Javeriana, Bogotá, Colombia
}

Urol Colomb 2021;30(3):e204-e209.

\begin{abstract}
Background and Objective Prostate cancer is a multifactorial disease and is among the top five causes of death in men worldwide. The Colombian Ministry of Health has adopted the Integrated Information System on Social Protection (Sistema Integrado de Información de la Protección Social, SISPRO, by its Spanish acronym) registry to collect comprehensive information from the Colombian health system. The system provides close to universal coverage (around 95\%). We aimed to establish the prevalence of prostate cancer in Colombia and to describe its demographics, based on data provided by SISPRO, openly available for scientific analysis.

Methods Using the SISPRO data from 2015 through 2019, we analyzed the prevalence and demographic characteristics of patients diagnosed with prostate cancer. Results We identified a total of 43,862 patients with prostate cancer in the 5-year

Keywords

- prostate cancer

- prevalence

- Colombia

- Latin America

- early-onset period and estimated a prevalence of 4.54 cases per 1,000 habitants, using as denominator males over 35 years old. We calculated a prevalence of early-onset prostate cancer (i.e., $35-54$ years) of 0.14 per 1,000 habitants ( 791 cases in 5 years). The highest prevalence was observed in patients $>80$ years (33.45 per 1,000 habitants). The departments with the highest prevalence were Bogotá, Valle del Cauca, Risaralda, and Boyacá, and the region with the lowest prevalence was Amazonas.
\end{abstract}

received July 25, 2020 accepted July 2,2021
DOI https://doi.org/ $10.1055 / \mathrm{s}-0041-1733844$. ISSN 0120-789X. e ISSN 2027-0119.

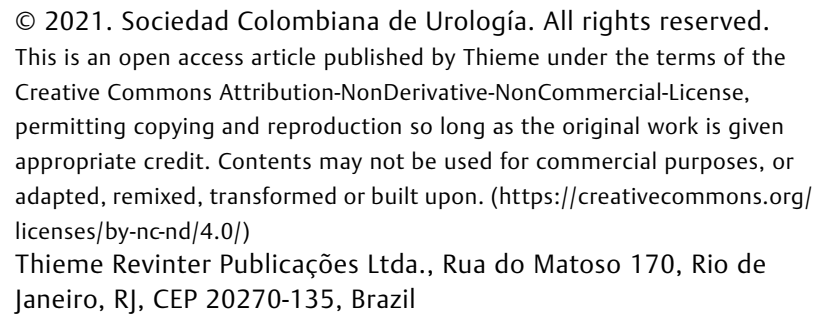

(c) 2021. Sociedad Colombiana de Urología. All rights reserved. This is an open access article published by Thieme under the terms of the Creative Commons Attribution-NonDerivative-NonCommercial-License, permitting copying and reproduction so long as the original work is given appropriate credit. Contents may not be used for commercial purposes, or adapted, remixed, transformed or built upon. (https://creativecommons.org/ licenses/by-nc-nd/4.0/) Thieme Revinter Publicações Ltda., Rua do Matoso 170, Rio de Janeiro, RJ, CEP 20270-135, Brazil 


\section{Resumen}

\author{
Palabras clave \\ - cáncer de próstata \\ - prevalencia \\ - Colombia \\ - América Latina \\ - inicio temprano
}

Conclusion We describe the prevalence and demographics of prostate cancer in Colombia using the national healthcare system database. We observed that the prevalence has been increasing over time, and the distribution is variable according to regions, which may be related to racial or environmental causes, or access to the urologist. These factors should be addressed in further studies.

Antecedentes y Objetivo El cáncer de próstata es una enfermedad multifactorial, y se encuentra entre las cinco principales causas de muerte en hombres a nivel mundial. El Ministerio de Salud de Colombia ha adoptado el Sistema Integrado de Información de la Protección Social (SISPRO) para la recopilación de la información integral del sistema de salud colombiano. El sistema proporciona una cobertura casi universal (alrededor del 95\%). El objetivo de este estudio fue establecer la prevalencia del cáncer de próstata en Colombia y describir su demografía, con base en los datos proporcionados por el SISPRO, disponibles de forma abierta para el análisis científico.

Métodos Utilizando los datos del SISPRO de 2015 a 2019, se analizaron la prevalencia y las características demográficas de los pacientes diagnosticados con cáncer de próstata.

Resultados Se identificó un total de 43,862 pacientes con cáncer de próstata en el período de 5 años, con una prevalencia de 4,54 casos por cada mil habitantes, utilizando como denominador hombres mayores de 35 años. La prevalencia de cáncer de próstata de inicio temprano (es decir, paciente de 35 a 54 años) fue de 0.14 por mil habitantes (791 casos en 5 años). La mayor prevalencia se observó en pacientes $>80$ años (33,45 por mil habitantes). Los departamentos con mayor prevalencia fueron Bogotá, Valle del Cauca, Risaralda, y Boyacá. Y la región con menor prevalencia fue Amazonas.

Conclusión Describimos la prevalencia y la demografía del cáncer de próstata y el cáncer de próstata de inicio temprano en Colombia utilizando la base de datos del sistema nacional de salud. Observamos una distribución desigual de la prevalencia entre las regiones, que puede estar relacionada con factores raciales, ambientales, o de acceso, que justifican más estudios.

\section{Introduction}

Prostate cancer (PCa) is a multifactorial disease that is considered a public health issue. According to the Global Cancer Observatory (GLOBOCAN), 1,276,106 new cases of PCa were registered worldwide, representing $7.1 \%$ of all cancers in men. ${ }^{1,2}$ Age is a major risk factor and a median age of diagnosis of 66 years has been reported. Other wellestablished non-modifiable risk factors are genetic susceptibility, black ethnicity, and family history. Its association with other modifiable factors, such as chemical contaminants, diet, and medications, among others, is not yet clear. ${ }^{3}$

The annual incidence of PCa has been increasing worldwide thanks to better cancer surveillance programs. The screening for and management of early PCa are some of the most challenging and controversial issues in medicine. ${ }^{4}$ In the last years, several countries in Latin America, including Brazil, Chile, Costa Rica, Mexico, Peru and Colombia, made PCa a public health priority in their national cancer plans; guidelines for early detection, diagnosis, treatment and follow-up have been developed. ${ }^{5,6}$ In Colombia, PCa is the most frequent cancer in men and the second cause of mortality in the male population, with a mortality rate of 12 per 100,000 people. $^{1}$

The present study aimed to establish the prevalence of PCa in Colombia and to describe its demographics, based on data provided by the Integrated Information System on Social Protection (Sistema Integrado de Información de la Protección Social, SISPRO, by its Spanish acronym). This system is the official administrative registry of the Colombian Ministry of Health.

\section{METHODS}

\section{Database Search}

Colombia has one of the widest health coverages in Latin America: $95.97 \%$ of the 50.5 million inhabitants as of April 2020, according to official data from the Colombian Ministry of Health. ${ }^{7}$ The Ministry developed an information database called SISPRO, which stores and processes the basic 
data that the system requires for its regulation and control processes. Demographics and clinical data are grouped in the Individual Health Services Delivery Registry (Registro Individual de Prestación de Servicios de Salud, RIPS, by its Spanish acronym), which are collected by medical staff during each outpatient or inpatient medical contact. This consolidated registry receives input from different sources: both private and public health providers, insurers, and other sources, such as RIPS, the Unified Affiliate Registry (Registro Único de Afiliados, RUAF, by its Spanish acronym), the System of Public Health Surveillance (Sistema de Vigilancia en Salud Pública, SIVIGILA, by its Spanish acronym), high-cost account, among others. These databases are publicly available for scientific analysis (http://www.sispro.gov.co/); the information to carry out this study was retrieved from the online dynamic tables. We have described searching methods previously. ${ }^{8-11}$ Due to recent updates on the database, the currently available information comprises only the period between 2015 and 2019. Briefly, we obtained the information for the whole country, for the period between January $1^{\text {st }} 2015$ and December $31^{\text {th }} 2019$. We analyzed the RIPS database using the International Classification of Diseases code for PCa (ICD-10 code: C61). ICD-10 codes: D075 (In situ carcinoma of the prostate) and D400 (tumor of uncertain or unknown behavior of the prostate) were not included to avoid bias. Following the Strengthening the Reporting of Observational Studies in Epidemiology (STROBE) guidelines, we analyzed the distribution in 5year age groups, according to the data from the most recent census, which was performed in 2018 with results published in the second semester of 2019. ${ }^{12}$

Prevalence per 1,000 inhabitants was calculated using as numerator the number of males diagnosed with PCa (counted once). The denominator was the number of inhabitants reported by the National Administrative Department of Statistics (Departamento Administrativo Nacional de Estadística, DANE, by its Spanish acronym) in each age group or geographical area. To calculate the prevalence, we included only men older than 35 years. We selected 35 years as the age threshold, as PCa diagnosis below this age is extremely rare; thus, the recorded cases under this age are probably due to codification errors, and their inclusion would imply that the prevalence calculation would be based on a larger denominator that could underestimate the real prevalence. Besides, we determined the prevalence of early-onset PCa (EO-PCa), defined as PCa diagnosis in patients $<55$ years (but older than 34 years), as mounting evidence supports differential pathophysiology that warrants further research. ${ }^{13}$ Data were recorded and analyzed using Microsoft Excel (Microsoft Corp., Redmond, WA, USA).

\section{RESULTS}

After removing cases under 35 years of age $(n=51)$, a total of 43,862 cases of patients with a primary diagnosis of PCa (both from outpatient and hospital services) were attended at some point during the 5 years (2015-2019). - Table 1 shows the number of cases per year divided by age group. The unadjusted prevalence in the 5 -year period was 4.54 cases per 1,000 habitants. The highest prevalence was observed in patients $>80$ years ( 33.45 per 1,000 habitants). The prevalence of EO-PCa was 0.14 cases per 1,000 habitants. - Fig. 1 shows the number of cases by age group and by year, with the highest being in 2019.

Regarding the distribution of PCa by departments, the prevalence ranged from 0.42 to 6.45 per 1,000 habitants. The departments with the highest prevalence were Bogotá (capital city of Colombia), Valle del Cauca, the Colombian coffee trail (Risaralda) and Boyacá. The lowest prevalence was observed in the region of Amazonas (Amazonas, Vaupés, Guaviare, and Vichada) (-Table 2 and -Fig. 2).

\section{DISCUSSION}

Colombia has a national health system that serves 63,000 new cases of cancer annually. ${ }^{14}$ The most prevalent malignancies in

Table 1 Patients with a main diagnosis of prostate cancer according to age between 2015 and 2019

\begin{tabular}{|l|l|l|l|l|l|l|l|}
\hline $\begin{array}{l}\text { Age group } \\
\text { (years) }\end{array}$ & $\mathbf{2 0 1 5}$ & $\mathbf{2 0 1 6}$ & $\mathbf{2 0 1 7}$ & $\mathbf{2 0 1 8}$ & $\mathbf{2 0 1 9}$ & $\begin{array}{l}\mathbf{5} \text {-year } \\
\text { total cases }\end{array}$ & $\mathbf{x 1 , 0 0 0}$ \\
\hline $\mathbf{3 5 - 3 9}$ & & 4 & 5 & 7 & 9 & 22 & 0.01 \\
\hline $\mathbf{4 0 - 4 4}$ & 2 & 6 & 11 & 9 & 17 & 37 & 0.03 \\
\hline $\mathbf{4 5 - 4 9}$ & 17 & 20 & 21 & 47 & 63 & 123 & 0.09 \\
\hline $\mathbf{5 0 - 5 4}$ & 65 & 84 & 146 & 278 & 384 & 609 & 0.47 \\
\hline $\mathbf{5 5 - 5 9}$ & 250 & 278 & 492 & 805 & 1,079 & 1,759 & 1.55 \\
\hline $\mathbf{6 0 - 6 4}$ & 719 & 796 & 1,090 & 1,805 & 2,349 & 4,002 & 4.42 \\
\hline $\mathbf{6 5 - 6 9}$ & 1,321 & 1,381 & 1,835 & 3,044 & 3,751 & 6,612 & 9.61 \\
\hline $\mathbf{7 0 - 7 4}$ & 1,832 & 1,900 & 2,430 & 3,974 & 4,674 & 8,495 & 17.25 \\
\hline $\mathbf{7 5 - 7 9}$ & 2,092 & 2,119 & 2,404 & 3,825 & 4,426 & 8,506 & 26.18 \\
\hline $\mathbf{8 0 - \text { older }}$ & 4,205 & 3,890 & 3,765 & 5,371 & 5,700 & 13,697 & 33.45 \\
\hline Total & 10,503 & 10,478 & 12,199 & 19,165 & 22,452 & 43,862 & 4.54 \\
\hline
\end{tabular}

Note: Numbers do not add up since patients might be included in more than one cell. 


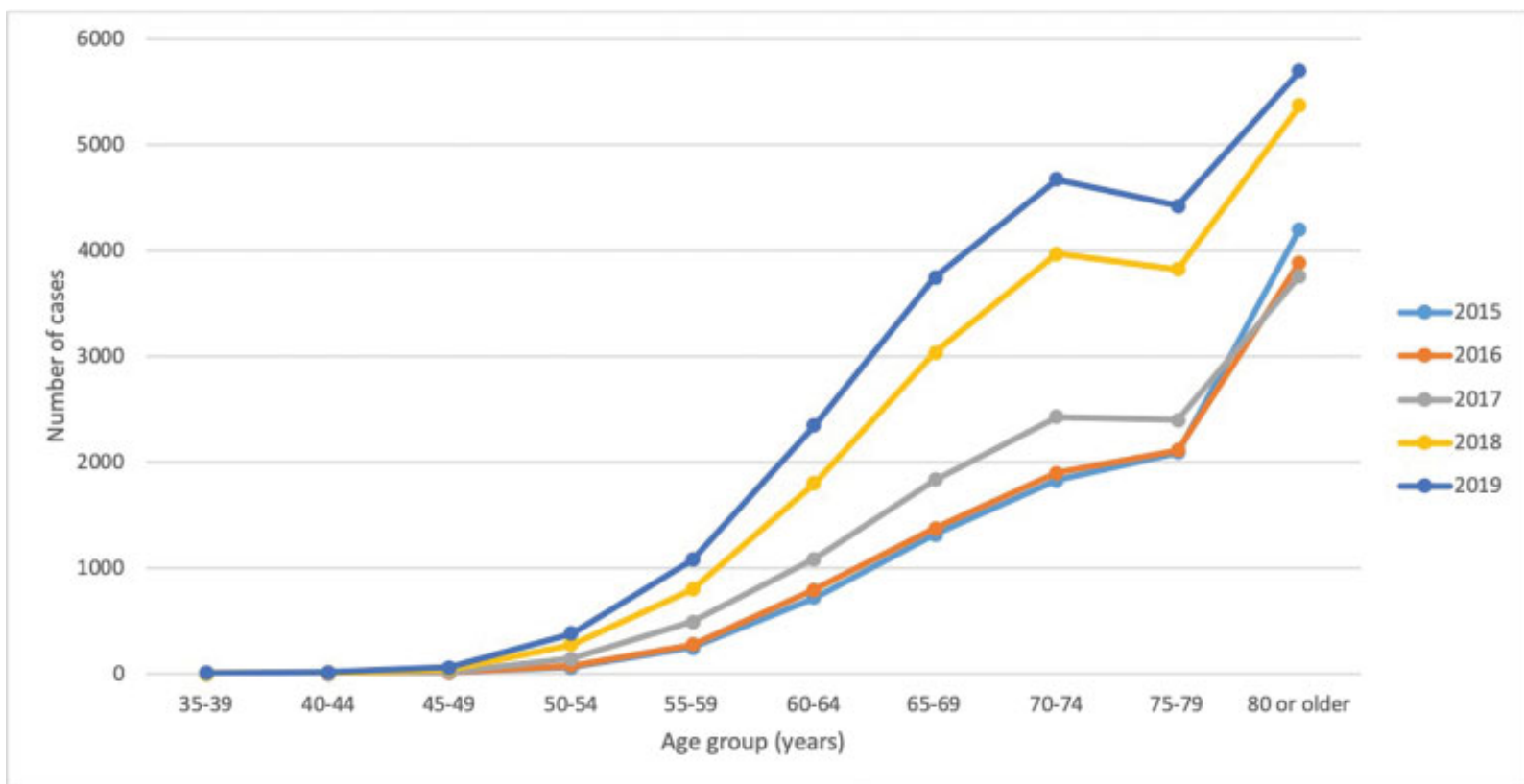

Fig. 1 Number of cases per age group (x 1,000 inhabitants).

men are prostate, stomach, colon, and lung. ${ }^{1,15}$ Based on the present study, the prevalence of PCa in 5 years was 4.54 cases per 1,000 habitants, and it has been increasing over time (-Fig. 1). The incidence rate reported in 2013 varies between 40.5 to 45.9 per 100,000 habitants. ${ }^{6}$ Data from Cali (southwest, capital city of Valle del Cauca) described that the age-standardized rate (ASR) changed from 22.3 per 100,000 males (1962-1966) to 64.8 per 100,000 males (2001-2005). ${ }^{16}$ Between 2003 and 2007, the ASR in Colombia was 54.4 per 100,000 males. ${ }^{5}$ According to data from high cost account (data present in SISPRO), in 2019, $37.7 \%$ of the PCa patients had a Gleason score (GS) of $6(3+3), 20.5 \%$ GS $7(3+4) ; 15.8 \%$ had a GS of $8,15.2 \%$ GS $7(4+3)$, and $10.8 \%$ had a GS of 9 or 10 . And the most frequent clinical stage was II (40.6\%) followed by stages I (27\%) and IV (20.1\%). ${ }^{17}$

The population in Latin America is heterogeneous regarding race, life expectancy, diet, and socioeconomic and cultural

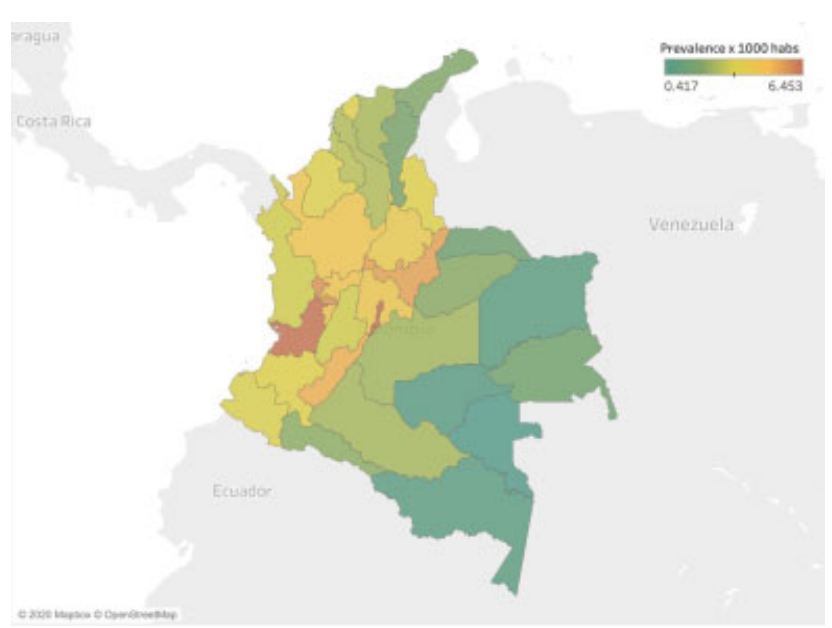

Fig. 2 Prevalence per Colombian department (x 1,000 inhabitants). levels. ${ }^{3}$ These factors may explain the differences in PCa epidemiology among countries. For instance, Brazil has the highest reported ASR (91.4 per 100,000 inhabitants) in the region, ${ }^{5}$ probably due to its high proportion of black race population, which stands out as a non-modifiable risk factor. ${ }^{18}$ In contrast, Peru has the lowest rate (34.6 per 100,000 inhabitants), ${ }^{5}$ probably due to the small proportion of people over 50 years old $(12 \%){ }^{3}$

Colombia is a country with several ancestry backgrounds. According to the 2005 census (DANE), $49 \%$ of the population is mestizo (mixed European and Amerindian ancestry), 37\% is of European ancestry (predominantly Spaniard), $10 \%$ is of African ancestry, and 3.4\% identify themselves as Amerindian. ${ }^{19}$ Interestingly, one of the regions with the highest PCa prevalence is Valle del Cauca (southwest). According to the 2018 census (DANE), ${ }^{12}$ this region has one of the largest proportions of Afro-Colombian inhabitants. It is noteworthy to point out that prevalence is also influenced by a high population density and a high number of available urologists. According to the Colombian Ministry of Health, the departments with the larger number of urologists are Bogotá (capital city of Colombia), Antioquia, Valle del Cauca, and Santander, ${ }^{6}$ a fact that is consistent with our data. On the other hand, the population density and urban development in the Amazonas regions is low (Amazonas, Vaupés, Guaviare and Vichada), which implies less access to specialists, and, therefore, a lower probability of obtaining an accurate diagnosis; this would explain the lower prevalence in this region. This phenomenon is supported by the fact that the registered cases in SISPRO are dependent on the official report made by the treating physician. Thus, patients from rural and less developed areas usually travel to larger cities to obtain a diagnosis, and, therefore, each case would be registered in that city; this implies that the calculated prevalence in less developed regions is underestimated. 
Table 2 Prevalence per Colombian department

\begin{tabular}{|l|l|}
\hline Department & Prevalence $\mathbf{x 1 , 0 0 0}$ habitants \\
\hline Bogotá, D.C. & 6.45 \\
\hline Valle del Cauca & 6.34 \\
\hline Risaralda & 5.73 \\
\hline Boyacá & 5.48 \\
\hline Huila & 5.22 \\
\hline Quindio & 4.59 \\
\hline Caldas & 4.51 \\
\hline Antioquia & 4.44 \\
\hline Cundinamarca & 4.29 \\
\hline Santander & 4.14 \\
\hline Norte de Santander & 3.65 \\
\hline Cauca & 3.58 \\
\hline Córdoba & 3.47 \\
\hline Atlántico & 3.47 \\
\hline Nariño & 3.39 \\
\hline Chocó & 3.26 \\
\hline Tolima & 3.24 \\
\hline Sucre & 2.91 \\
\hline Bolívar & 2.78 \\
\hline Magdalena & 2.65 \\
\hline Caquetá & 2.58 \\
\hline Meta & 2.55 \\
\hline Archipiélago de San Andrés & 2.34 \\
\hline Putumayo & 2.19 \\
\hline Casanare & 2.12 \\
\hline La Guajira & 2.03 \\
\hline Cesar & 1.88 \\
\hline Guainía & 1.60 \\
\hline Arauca & 1.51 \\
\hline Vichada & 0.76 \\
\hline Amazonas & 0.69 \\
\hline Guaviare & 0.64 \\
\hline Vaupés & 0.42 \\
\hline & \\
\hline
\end{tabular}

On the other hand, the prevalence of EO-PCa, defined as PCa under 55 years, was 0.14 cases per 1,000 habitants or (791 cases in 5 years). The incidence of EO-PCa has been increasing over the last years. For example, in the United States, it changed from 5.6 to 32 cases per 100,000 person years (confidence interval [CI] 95\% CI 5.0-6.7), making EOPCa an important emerging issue for public health. ${ }^{20,21}$ In $2012,10 \%$ (241,740 cases) of men $\leq 55$ years old were diagnosed with PCa. ${ }^{22}$ Different risk factors have been associated, such as family history, ethnicity, and genetic factors, ${ }^{23}$ and different studies have described differences in the molecular characteristics and the clinical behavior when compared with classic PCa. ${ }^{24-26}$
One of the limitations of our study is the possible underreporting by physicians in the medical records, especially because there are many occasions in which patients cannot access or continue with the medical assistance, especially in remote regions of the Colombian territory. In addition, the prevalence would be underestimated in underserved areas, as the formal diagnosis would be registered in larger cities.

In conclusion, to the best of our knowledge, this is the first study that describes the prevalence and demographics of PCa and EO-PCa in Colombia using the national healthcare registry. The prevalence has been increasing over time and it varies between the regions; the departments with the highest prevalence were Bogotá, Valle del Cauca, Risaralda, and Boyacá, and the region with the lowest prevalence was the Amazonas. This behavior may be related to racial and environmental causes as well as to access to appointment with the urologist, among others. These factors should be addressed in further studies.

Financing

This work does not present a source of financing.

Conflict of Interests

The authors declare no conflict of interests for this study.

Acknowledgement

We want to thank Dr. Nancy Herrera for her advice on data extraction and invaluable insight on our manuscript.

\section{References}

1 Bray F, Ferlay J, Soerjomataram I, Siegel RL, Torre LA, Jemal A. Global cancer statistics 2018: GLOBOCAN estimates of incidence and mortality worldwide for 36 cancers in 185 countries. CA Cancer J Clin 2018;68(06):394-424

2 Rawla P. Epidemiology of Prostate Cancer. World J Oncol 2019;10 (02):63-89http://www.wjon.org/index.php/WJON/article/view/ 1191[Internet]

3 Gandhi J, Afridi A, Vatsia S, et al. The molecular biology of prostate cancer: current understanding and clinical implications. Prostate Cancer Prostatic Dis 2018;21(01):22-36

4 Cuzick J, Thorat MA, Andriole G, et al. Prevention and early detection of prostate cancer. Lancet Oncol 2014;15(11):e484-e492

5 Sierra MS, Soerjomataram I, Forman D. Prostate cancer burden in Central and South America. Cancer Epidemiol 2016;44(Suppl 1): S131-S140

6 Guía de práctica clínica para la detección temprana, diagnóstico, tratamiento, seguimiento y rehabilitación del cáncer de próstata| GPC-2013-21. Instituto Nacional de Cancerología ESE-Sociedad Colombiana de Urología 2013

7 Ministerio de Salud y Protección Social. Cifras de aseguramiento en salud con corte enero de. 2019https://www.minsalud.gov.co/proteccionsocial/Paginas/cifras-aseguramiento-salud.aspx

8 Fernández-Ávila DG, Bernal-Macías S, Rincón-Riaño DN, Gutiérrez Dávila JM, Rosselli D. Prevalence of systemic lupus erythematosus in Colombia: data from the national health registry 2012-2016. Lupus 2019;28(10):1273-1278

9 Fernández-Ávila DG, Rincón-Riaño DN, Bernal-Macías S, Gutiérrez Dávila JM, Rosselli D. Prevalence and Demographic Characteristics of Sjögren's Syndrome in Colombia, Based on Information from the Official Ministry of Health Registry. Reumatol Clin (Engl Ed). 2020; 16(04):286-289 
10 Fernández-Ávila DG, Bernal-Macías S, Rincón-Riaño DN, Gutiérrez JM, Rosselli D. Prevalence of polymyalgia rheumatica in Colombia: data from the national health registry 2012-2016. Rheumatol Int 2019;39(09):1631-1635

11 Alba LH, Alba M. S DO, Esteban MO, Rosselli D. Análisis De Los Registros Individuales De Prestación De Servicios De Salud (Rips) En Cáncer En Colombia. Medicina (B Aires) 2016;38(03):223-231

12 National Department of Statistics-DANE. 2018Censo Nacional de Población y Vivienda 2018-Colombia.

13 Gupta S, Gupta A, Saini AK, Majumder K, Sinha K, Chahal A. Prostate Cancer: How Young is too Young? Curr Urol 2017;9(04):212-215

14 Cendales R, Pardo C. Quality of death certification in Colombia. Colomb Med (Cali) 2018;49(01):121-127

15 Bravo LE, Muñoz N. Epidemiology of cancer in Colombia. Colomb medica (Cali. Colomb. 2018;49(01):9-12

16 Cancer incidence in five continents. Volume VIII. IARC Sci Publ 2002;(155):1-781

17 Situación del Cáncer en la población adultos atendida en el SGSSS de Colombia - 2019 Cuenta de Alto Costo. Fondo Colombiano de Enfermedades de Alto Costo [Internet]. 2019. Available from: https://cuentadealtocosto.org/site/publicaciones/situacion-delcancer-en-la-poblacion-adultos-atendida-en-el-sgsss-decolombia-2019/

18 Evans S, Metcalfe C, Ibrahim F, Persad R, Ben-Shlomo Y. Investigating Black-White differences in prostate cancer prognosis: A systematic review and meta-analysis. Int J Cancer 2008;123(02): 430-435

19 De Castro M, Restrepo CM. Genetics and genomic medicine in Colombia. Mol Genet Genomic Med 2015;3(02):84-91

20 Salinas CA, Tsodikov A, Ishak-Howard M, Cooney KA. Prostate cancer in young men: an important clinical entity. Nat Rev Urol 2014;11(06):317-323

21 Howlader N, Noone AM, Krapcho M, et al, Eds. SEER Cancer Statistics Review, 1975-2014, National Cancer Institute. Bethesda, MD. https://seer.cancer.go

22 Siegel R, Naishadham D, Jemal A. Cancer statistics, 2012. CA Cancer J Clin 2012;62(01):10-29

23 Hussein S, Satturwar S, Van der Kwast T. Young-age prostate cancer. J Clin Pathol 2015;68(07):511-515

24 Weischenfeldt J, Simon R, Feuerbach L, et al. Integrative genomic analyses reveal an androgen-driven somatic alteration landscape in early-onset prostate cancer. Cancer Cell 2013;23(02):159-170

25 Valera VA, Parra-Medina R, Walter BA, Pinto P, Merino MJ. microRNA Expression Profiling in Young Prostate Cancer Patients. J Cancer 2020;11(14):4106-4114

26 Parra-Medina R, López-Kleine L, Ramírez-Clavijo S, Payán-Gómez C. Identification of candidate miRNAs in early-onset and lateonset prostate cancer by network analysis. Sci Rep 2020;10(01): 12345. http://www.nature.com/articles/s41598-020-69290-7 [Internet] 